\title{
A SEMI-QUANTITATIVE METHOD FOR DETERMINING THE LEVELS OF CARBONIC ANHYDRASE ISOZYMES IN INDIVIDUAL RED BLOOD CELLS
}

\author{
J. DeSIMONE, L. M. DAUFI ${ }^{1}$ and R. E. TASHIAN
}

Department of Human Genetics, and Department of Physiology, University of Michigan Medical School, Ann Arbor, Mich. 48104, USA

\section{SUMMARY}

\begin{abstract}
A procedure is presented which can be used to analyse the isozymes of carbonic anhydrase (CA I and CA II) as well as other specific soluble proteins of individual erythrocytes. The concentration of red cell CA I in the pig-tailed macaque (Macaca nemestrina) was estimated by the technique employed, as well as the relative concentration in individual cells. In addition, the basic technique was modified to include electrophoresis of the carbonic anhydrases of the individual cells.
\end{abstract}

Recently Gitlin et al. [1] and Daufi \& Rondell [2] independently reported immunochemical methods for the analysis of carbonic anhydrase and other specific soluble proteins in individual human red blood cells. Although

${ }^{1}$ Present address: Facultad de Medicina, Hospital de San Pablo, Universidad Autonoma de Barcelona, Barcelona, Spain. the method of Gitlin et al. [1] has been shown to be useful for quantitation, it does not allow direct visualization of both the cell and its contents at the same time. The method of Daufi \& Rondell [2] has not been shown to be quantitative; however, it does permit direct visualization and we feel this attribute lends a flexibility not afforded by other

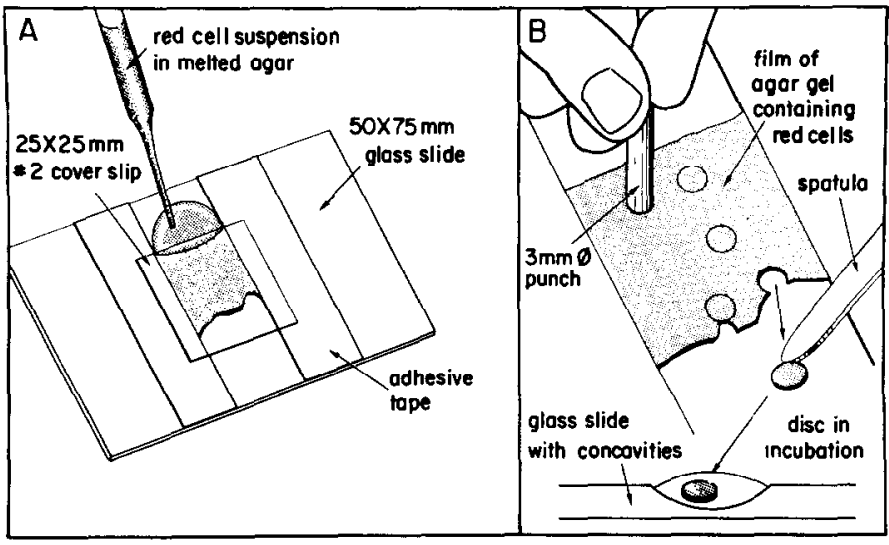

Exptl Cell Res 67
Fig. 1. (A) Illustration of the method used in preparing the thin films of red blood cells embedded in agar. (B) Illustration of the procedure used for cutting and transferring the $3 \mathrm{~mm}$ discs. 

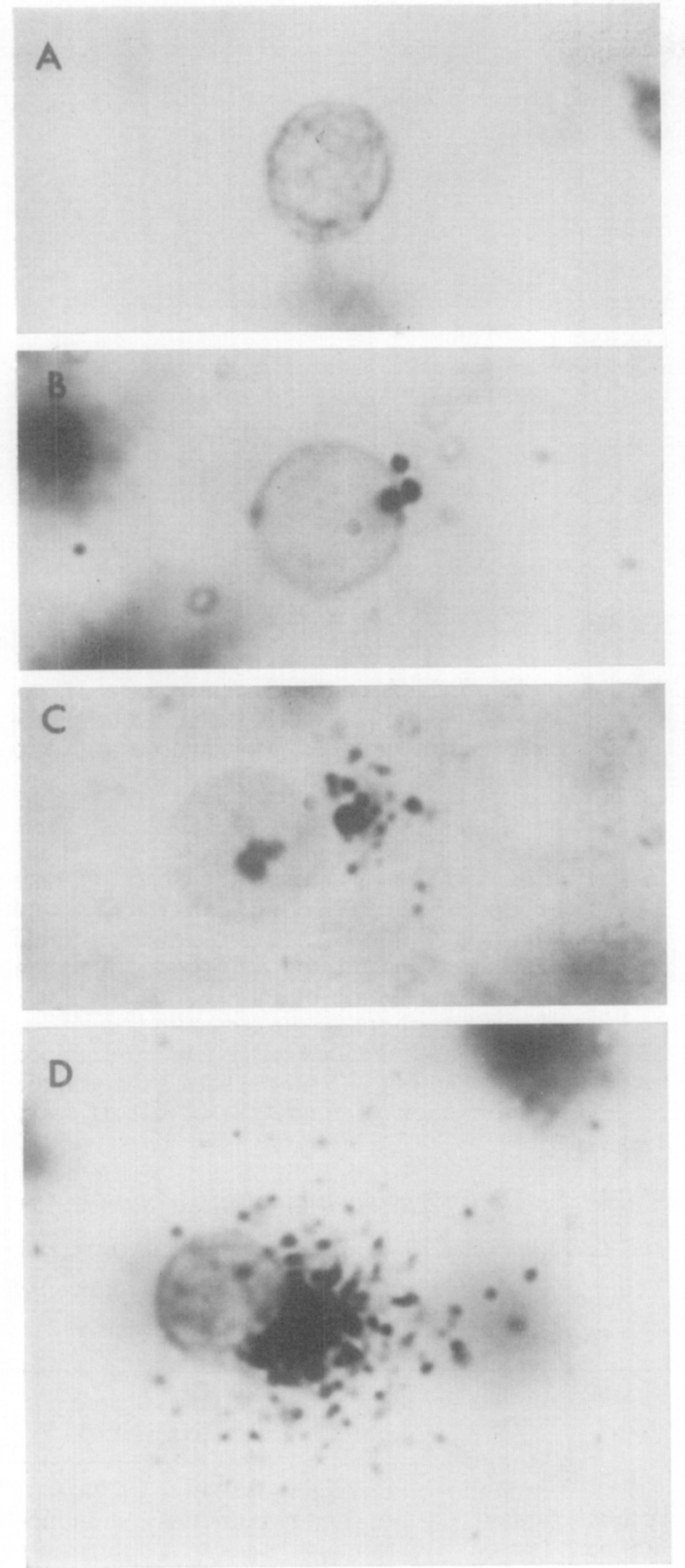

Fig. 2. $(A-D)$ Red blood cells from a single Macaca nemestrina demonstrating the wide range of immunoprecipitin granules of CA I produced. The darklystaining granules can be seen outside of cells $(B),(C)$, and $(D)$.

assays. Therefore, an attempt was made to extend the method for use as a quantitative tool.
The red cells used in this study were obtained from the pig-tailed macaque, Macaca nemestrina. This species was chosen for studies on the quantitation of carbonic anhydrase in individual red blood cells because, not only is there marked quantitative variation in one of its carbonic anhydrase isozymes, carbonic anhydrase I (CA I), but there is also an inherited deficiency of CA I which results in a reduction of this enzyme to $0.02 \%$ of normal levels $[3,4]$.

\section{MATERIALS AND METHODS}

The technique consists of: (a) suspending red cells in a thin sheet of agar; $(b)$ diffusing antibody through the gel surrounding the cells; (c) lysing the cells; and $(d)$ examining by light microscopy, the immunoprecipitin granules formed as the cell contents diffuse into the surrounding agar.

(a) The thin film of red cells is prepared by suspending $3 \times$ washed red cells in $1 \%$ agar in saline cooled to $38-40^{\circ} \mathrm{C}$. The concentration of cells in the agar is $0.25-0.50 \%$; a concentration which allows adequate separation of the cells. The mixture is allowed to gel into a thin sheet between a slide and coverslip previously prepared as shown in fig. $1 a$. Once the agar has gelled, the coverslip is removed and, with the aid of a tubular punch, 3-mm diameter discs are cut from the agar (fig. $1 b$ ). These discs can be easily manipulated through all the operations of the procedure, and the cells contained in them can be conveniently observed under the microscope.

(b) The discs are then placed into a microconcavity slide containing rabbit anti-human carbonic anhydrase I prepared as described by Tashian et al. [5]. The antiserum was decomplemented before use by heating to $56^{\circ} \mathrm{C}$ for $\frac{1}{2} \mathrm{~h}$. Complement must be removed or the cell membranes will be disintegrated. The discs are allowed to incubate at room temperature for $\frac{1}{2} \mathbf{h}$ in a Petri dish lined with moistened filter paper to avoid evaporation.

(c) After $\frac{1}{2} \mathrm{~h}$ the discs are transferred to a second microconcavity slide containing anti-CA I plus $0.3 \%$ Triton X-100. The cells in this concentration of Triton $\mathrm{X}-100$ will lyse gently, and the contents of the cell will diffuse through a single hole in the membrane (figs 2,3 ). It was found that this type of lysis facilitated quantitation of the immunoprecipitates.

(d) The immunoprecipitates were prepared for light photomicroscopy as described by Daufi \& Rondell [2]. The cells are fixed in osmium tetroxide, mordanted in $4 \%$ ferric ammonium sulfate, and stained in $5 \%$ hematoxylin. The quality of the precipitin granules can be seen in figs 2,3 .

Quantitation of $\mathrm{Ca}$ I was performed by counting the individual immunoprecipitin granules formed from each cell. This was accomplished by photographing single cells on high contrast copy film and projecting 


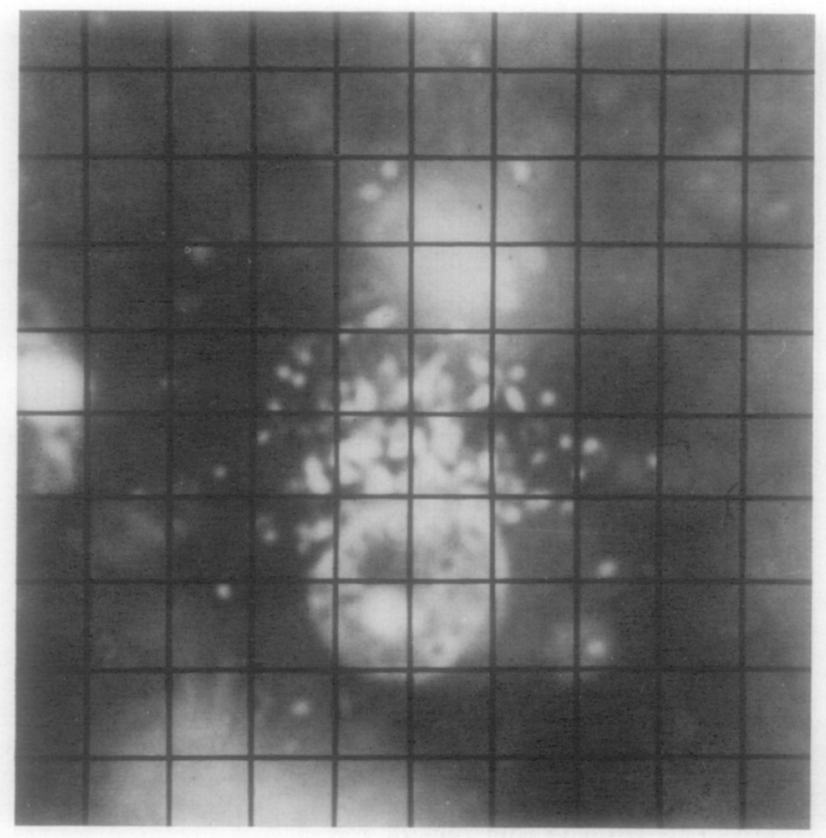

Fig. 3. High contrast negative of a $M$. nemestrina red blood cell, with CA I immunoprecipitin granules, projected on a grid to facilitate counting. the negatives on a microcomparator. To facilitate counting, a grid was prepared as shown in fig. 3. As can be seen, the grauules can be easily counted.

The concentration of CA I ( $\mu \mathrm{g} / \mathrm{ml}$ of hemolysate) was accurately determined for each preparation by the radioimmunological procedure of Headings \& Tashian [3]. The absolute concentrations as determined from this assay were used to compare relative concentrations determined from the single cell granule counts.

The basic procedure outlined above does not give satisfactory granule formation when the other carbonic anhydrase isozyme, carbonic anhydrase II (CA II) is analysed. As is demonstrated in fig. $4 a$, when an anti-serum specific for CA II is used, most of the immunoprecipitin granules formed are located within the cell. Therefore, a comparison of CA I and $\mathrm{Ca}$ II by this method was not possible. In order to produce a granule pattern similar to that of CA I, it was necessary to subject the cells to electrophoresis. The electrophoretic procedure was carried out in the following way. Thin films of red cells are prepared as outlined above, except $0.1 \mathrm{ml}$ of $2 \times$ concentrated anti-serum was added directly to $0.1 \mathrm{ml}$ of melted $2 \%$ agar made up in phosphate-buffered saline $(\mathrm{pH} 7.0)$ prior to the addition of cells and subsequent electrophoresis. The coverslip was not removed, and the excess agar was used for contacts for the paper wicks used in the electrophoresis. Leaving the coverslip in place aided in maintaining equilibrium during electrophoresis. The electrophoresis was carried out for 1 minute with a voltage gradient of $70 \mathrm{~V} \mathrm{~cm}^{-1}$. The cells lyse as a result of this electrophoretic procedure, and the contents migrate from the cell into the agar. Precipitation of CA II occurs rapidly once in contact with the anti-serum.
The anti-CA II serum used for the electrophoresis was partially purified by $\left(\mathrm{NH}_{4}\right)_{2} \mathrm{SO}_{4}$ precipitation and the pellet resuspended in $\mathrm{H}_{2} \mathrm{O}$ to one-half the original volume. The $2 \times$ concentrated anti-serum was then dialysed against phosphate buffered saline pH 7.0

After the electrophoresis, the coverslip is removed and the film of agar-embedded cells is fixed and stained as described above. Fig. $4(b$ and $c$ ) shows the granule pattern and direction of migration of CA II from two cells.

Table 1. Comparative quantitative values for red cell carbonic anhydrase I in $\mathrm{M}$. nemestrina using the cytoimmunodiffusion technique and the radioimmunoassay

\begin{tabular}{|c|c|c|c|c|}
\hline \multirow[b]{2}{*}{$\begin{array}{l}\text { Animal } \\
\text { number }\end{array}$} & \multirow[b]{2}{*}{$\begin{array}{l}\text { Radio- } \\
\text { immuno- } \\
\text { assay } \\
(\mu \mathrm{g} / \mathrm{ml})\end{array}$} & \multirow{2}{*}{$\begin{array}{l}\text { Cyto- } \\
\text { immuno- } \\
\text { diffusion } \\
\text { (average } \\
\text { no. } \\
\text { granules) }\end{array}$} & \multicolumn{2}{|c|}{ Relative value $^{a}$} \\
\hline & & & $\begin{array}{l}\text { Radio- } \\
\text { immuno- } \\
\text { assay }\end{array}$ & $\begin{array}{l}\text { Cyto- } \\
\text { immuno- } \\
\text { diffusion }\end{array}$ \\
\hline 1 & 1510 & 134.50 & 100 & 100 \\
\hline 2 & 850 & 78.99 & 56.29 & 58.73 \\
\hline 3 & 1220 & 104.60 & 80.79 & 77.77 \\
\hline 4 & 800 & 68.97 & 52.98 & 51.28 \\
\hline 5 & 0.27 & $0.0^{b}$ & 0.00017 & 0.0 \\
\hline 6 & 0.35 & $0.0^{b}$ & 0.00023 & 0.0 \\
\hline
\end{tabular}

${ }^{a}$ Relative concentration using animal number 1 as basis for comparison.

${ }^{b}$ Below the sensitivity of the assay. 


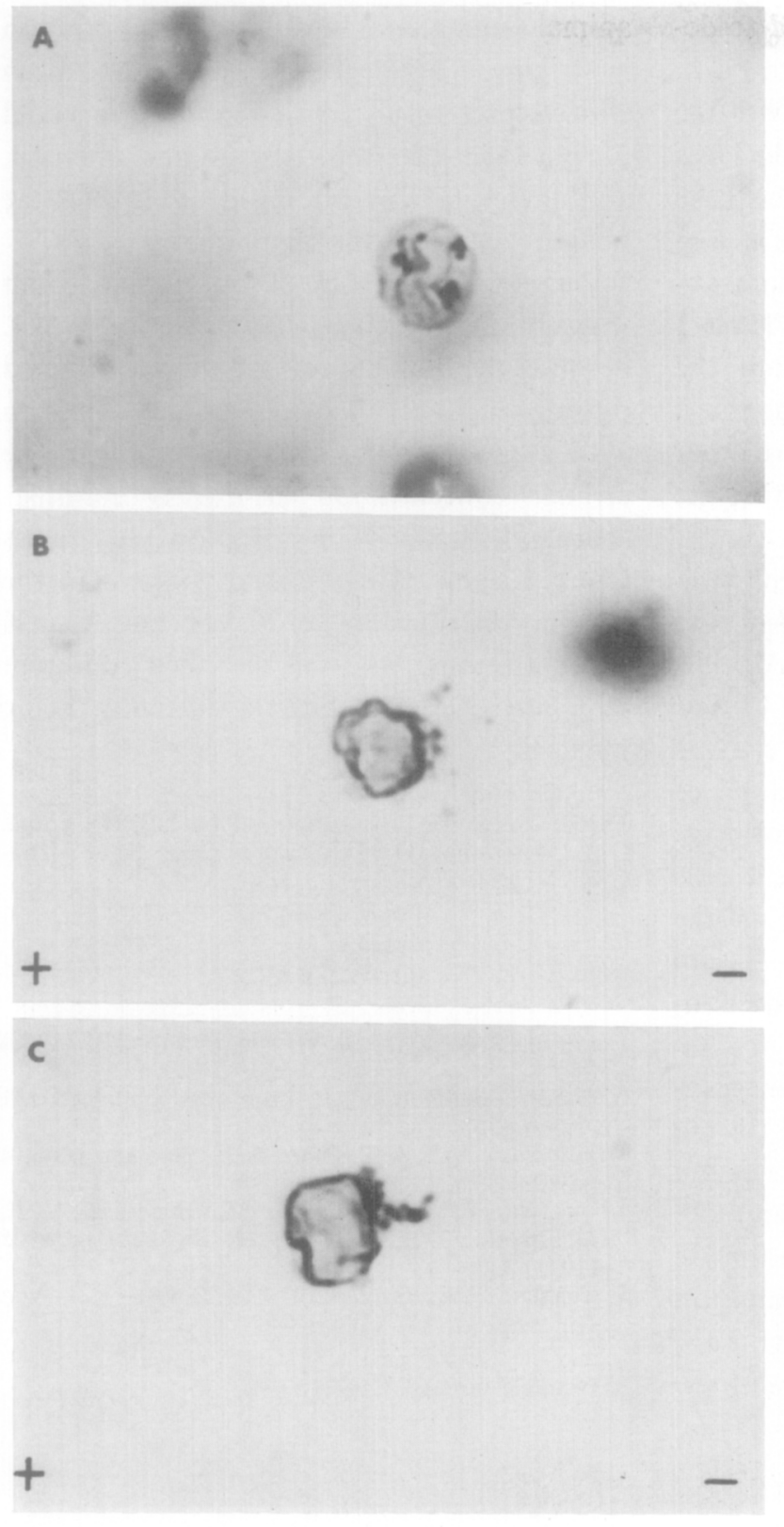

Fig. 4. (A) Immunoprecipitin granules of CA II located inside a red blood cell of $M$. nemestrina. $(B, C)$ Immunoprecipitin granule patterns of CA II produced by red cells in an electric field. Electrophoresis was carried out for $1 \mathrm{~min}$ with a voltage gradient of $70 \mathrm{~V} \mathrm{~cm}-1$. The anode is to the left and cathode to the right.

\section{RESULTS AND DISCUSSION}

Six pig-tailed macaques were chosen for this investigation. A single blood sample was drawn from each animal, and an aliquot of intact cells was removed for use in the single cell assay. The rest of the cells were lysed for use in the radioimmunoassay.

The single cell assay was performed on each sample as described above. One hundred cells were chosen at random, photographed, and granule counts were made for each cell. 
The mean granule numbers were used to determine the relative protein concentrations. This was done by using the animal with the highest mean number of granules as the basis for comparison. Ratios relative to this base were computed for the other animals, and similar ratios were calculated from data obtained from the radioimmunoassay. Table 1 shows the ratios obtained using both the granule count and the radioimmunoassay. As can be seen, the ratios calculated by either method are nearly identical, indicating the quantitative potential of the assay.

Animals 5 and 6 are CA I deficient individuals and have enzyme levels below the sensitivity of the single-cell method. All cells from these two animals are identical to that shown in fig. $2 a$. Even though the enzyme levels in these cells were below the level of detection, they were useful as control cells. It is obvious from these CA I deficient cells that the immunoprecipitates formed in the non-deficient animals (numbers 1-4) are specifically due to CA I and not to any nonspecific CA II cross-reactivity.

Having demonstrated that the mean granule count gives a reliable estimate of the total relative concentration of enzyme, it can be assumed that the number of granules produced by a single cell is also an estimate of that individual cell's CA I concentration relative to that of other cells. Fig. $2 a-d$ shows a series of cells taken from a single animal (animal 3). The range of concentration is striking. This degree of cellular variation with respect to enzyme concentration could not have been determined by any other method, and therefore this finding demonstrates the obvious value of this technique.

Quantitation of CA II by granule count was not performed as described for CA I, because the number of granules contained outside each cell was remarkably uniform within each animal. This uniformity in the cellular concentration of CA II contrasts sharply with the wide variation seen in its CA I isozyme. This marked contrast in the cellular distributions of CA I and CA II concentrations, as well as their different diffusion characteristics, is currently being pursued.

This investigation was supported by USPHS grants GM 15419 and HD 03470, and training grant 5-T01GM-71-11 (J. D.).

\section{REFERENCES}

1. Gitlin, D, Sasaki, T \& Vuopio, P, Blood 32 (1968) 796.

2. Daufi, L \& Rondell, P, Proc exptl biol med 131 (1969) 1353.

3. Headings, V E \& Tashian, R E, Biochem genet 4 (1970) 285 .

4. Tashian, R E, Goodman, M, Headings, V E, DeSimone, J \& Ward, R H, Biochem genet 5 (1971) 183.

5. Tashian, R E, Shreffler, D C \& Shows, T B, Ann NY acad sci 151 (1968) 64.

Received February 7, 1971. 